\title{
Upaya Pelestarian Ekosistem Karst Gunungsewu Melalui Kegiatan Membatik pada Masyarakat Desa Ginggang, Pracimantoro, Wonogiri, Jawa Tengah
}

\author{
$1 *$ Kuswaji Dwi Priyono, ${ }^{2}$ Herry Purnama, ${ }^{3}$ Alpha Fabela Priyatmono \\ ${ }^{1}$ Prodi Geografi, Fakultas Geografi UMS \\ ${ }^{2}$ Prodi Teknik Kimia, Fakultas Teknik UMS \\ 3Prodi Teknik Arsitektur, Fakultas Teknik UMS \\ *Penulis korespondensi, email: kdp130@ums.ac.id
}

(Received: 1 July 2020/Accepted: 6 July 2020/Published: 7 July 2020)

\begin{abstract}
Abstrak
Program Pengabdian kepada Masyarakat di Desa Ginggang, Kecamatan Pracimantoro, Kabupaten Wonogiri bertujuan untuk mendampingi Ibu-ibu PKK dalam proses membatik sekaligus sosialisasi upaya pelestarian ekosistem karst Gunungsewu. Metode yang digunakan adalah pelatihan praktek penciptaan batik Karst Gunungsewu, estetika batik Kawasan Karst Gunungsewu, dan pemasaran produk Desa Batik Karst Gunungsewu, terkait solusi pemasaran produk dengan luaran inovasi dan merek dagang batiknya. Penciptaan Batik Karst Gunungsewu: (1) membuat pola pada kain; (2) penglowongan, proses pemalaman atau pelekatan malam dengan teknik canthing/kuas; (3) pewarnaan batik dengan teknik esek dan teknik celup; (4) Njupiki atau proses pemalaman; (5) pewarnaan kedua untuk melebur dan meratakan; dan (6) pelorodan, perebusan yang dilakukan untuk melepaskan dan membersihkan malam yang melekatpada kain. Dalam kegiatan terkait Estetika Batik, meliputi: (1) pelatihan pemahaman filosofi geomorfologis terbentuknya bentangalam karst dan filosofi pewarnaan; (2) menerjemahkan gambaran morfologis karst; (3) p elatihan nilai tambahan pada motif yang diterapkan yangmemilikimaknapelestarian bentangalam kawasan karst. Selesainya kegiatan, masyarakat dapat membuat produk batik dengan motif bentangalam karst dan memahami pentingnya pelestarian ekosistem karst.
\end{abstract}

Kata Kunci : batik, pelestarian, ekosistem karst, dan desa wisata

\begin{abstract}
The Community Service Program in Ginggang Village, Pracimantoro District, Wonogiri Regency aims to assist PKK womens in the process of making batik and at the same time socializing efforts to preserve the Gunungsewu Karst Ecosystem. The methods used were training in the practice of creating Gunungsewu Karst batik, the aesthetics of the Gunungsewu Karst Area batik, and the marketing of Gunungsewu Karst Batik Village products. , related to product marketing solutions with innovation and trademark batik. Creation of Gunungsewu Karst Batik: (1) making patterns on fabric; (2) penglowongan, the process of deepening or sticking the night with canthing / brush techniques; (3) batik coloring using Esek technique and dye technique; (4) Njupiki or the process of experience; (5) second coloring for fusion and leveling; and (6) pelorodan, boiling carried out to remove and clean the wax attached to the cloth. In activities related to Batik Aesthetics, they include: (1) training in understanding the geomorphological philosophy of karst landscape formation and coloring philosophy; (2) translating morphological features of karst; (3) additional value training on the motives applied which have the meaning of preserving the landscape in the karst region. Completion of activities, the community can make batik products with karst landscape motifs and understand the importance of preserving the karst ecosystem.
\end{abstract}

Keywords: batik, preservation, karst ecosystem, and tourist village 


\section{Pendahuluan}

Pemberdayaan masyarakat lokal dalam pengembangan destinasi pariwisata menjadi sangat penting untuk keberlanjutan destinasi dan daya dukung obyek destinasi tersebut. Museum Karst Dunia merupakan asset nasional dan dunia internasional, telah 11 tahun ini menjadi destinasi wisata alam unggulan Pemerintah Kabupaten Wonogiri. Kawasan karst merupakan kawasan dengan karakteristik khas sebagai hasil proses solusional, yang dicirikan dengan adanya cekungan tertutup, bukit-bukit kerucut, maupunlorong-lorong yang berfungsi sebagai sistem aliran bawah permukaan (Nuraini dan Pramono, 2013). Dalam perkembangannya, berkembangnya destinasi museum karst belum diikuti oleh kawasan desa di sekitarnya. Sementara itu, desa di sekitar museum karst banyak mempunyai potensi local dari sisi budaya dan lingkungan alamnya untuk dikembangkan sebagai destinasi wisata yang terintegrasi dengan wisata Museum Karst. Salah satu budaya lokal yang potensial untuk dikembangkan di desa kawasan karst adalah batik. Batik di Desa Ginggang pernah eksis di kawasan karst ini, namun karena kurang adanya pembinaan maka kurang berkembang.

Masyarakat Desa Ginggang, Kecamatan Pracimatoro, Kabupaten Wonogiri selama ini kebanyakan hanya sebagai penonton keberadaan Museum Karst, sebagian kecil yang berdekatan dengan Museum beraktivitas sebagai pedagang minuman dan jasa parkir saja. Beberapa orangtua (pinisepuh) di Desa Ginggang dahulu pernah bekerja sebagai tukang batik pada beberapa pengusaha batik di Kampung Laweyan di Kota Surakarta, anak turunnya sangat berminat untuk didampingi menjadi pembatik juga. Kepala Desa Ginggang mewakili masyarakat Desa telah dipertemukan dengan Pengusaha Batik yang tergabung pada Forum Pengembangan Kampoeng Batik Laweyan Kota Surakarta oleh Tim Pengabdian Masyarakat UMS. Mereka telah bersepakat untuk mengembangkan Desa Wisata Batik Kawasan Karst Gunungsewu, sebagai Mitra 1 (Masyarakat Desa Ginggang) dan Mitra 2 (Forum Pengembangan Kampoeng Batik Laweyan) dengan misi utama kegiatan membantik sebagai upaya masyarakat dalam pelestarian ekosistem Kawasan Karst Gunungsewu .

Dipilihnya program kegiatan pengabdian masyarakat berbasis Desa Batik ini karena batik Indonesia telah dinobatkan sebagai warisan budaya milik dunia (World Heritage) berdasarkan pengukuhan UNESCO (The United Nations Educational, Scientific and Cultural Organization) pada tanggal 2 Oktober 2009 (Lusianti, \& Rani, 2012). Batik adalah kain tekstil bermotif khas Indonesia dari hasil pewarnaan yang penciptaannya melalui proses perintangan menggunakan lilin batik atau malam (Moersid, 2013). Motif batik merupakan unsur pokok sebuah ornamen, melalui ornamen dapat dikenali perwujudan motif pada umumnya sebagai gubahan atas bentukbentuk di alam atau sebagai representasi alam yang kasat mata (Ulum, 2016). Keunikan motif batik pada kegiatan ini dibangun bermotif keunikan ornament bentang alam kawasan karst Gunungsewu. Museum Karst di Desa Ginggang, Kecamatan Pracimantoro, yang diresmikan oleh Presiden Susilo Bambang Yudhoyono kala itu pada tanggal 30 Juni 2009 ini merupakan Museum Karst terbesar dan terunik di Indonesia bahkan dunia (Widawati, Rindarjono, \& Soegiyanto, 2017).Wonogiri merupakan salah satu kabupaten yang berada di bagian tenggara wilayah Provinsi Jawa tengah, Indonesia. Wilayah seluas 1.822 .037 kilometer persegi ini memiliki berpuluh-puluh gua karst yang terbentuk secara alami. Gua-gua ini terbentuk akibat proses evolusi bumi dan pukulan arus air secara terus menerus selama berabad-abad lamanya. Banyak gua yang menakjubkan di Wonogiri ini terdapat sungai bawah tanah seperti Gua Mrica, Gua Proto, Gua Tembus, Gua Sapen, Gua Sonya Ruri, Gua Sodong atau Gua Gilap(Tyas,Vitdiawati, \& Nusantari, 2016). Museum ini memang sengaja dibangun di kawasan perbukitan Gamping, bertujuan agar para wisatawan yang berkunjung dapat belajar mengenai Batuan Karst dan Sejarah Gua. Selain sebagai tempat wisata, berkunjung ke Museum Karst Wonogiri ini akan mendapatkan nilai pendidikan dan turut menjaga keberadaan situs-situs di sekitar Museum Karst Wonogiri. 
Permasalahan Mitra 1 selama ini hanya sebagai penonton keberadaan Museum Karst Dunia yang berada di tengah desanya, sebagai anak dan cucu pembatik mereka ingin didampingi dalam pembuatan batik yang khas dan terintegrasi dengan pengenalan kawasan karst Gunungsewu. Pendampingan yang diinginkan juga menyangkut potensi pewarna alami sebagai sumberdaya alam local dengan pola-pola motif batik yang menggambarkan informasi kekhasan bentangalam Karst Gunungsewu. Mitra 1 telah bersepakan menjadikan kawasan desanya sebagai Desa Wisata Batik yang berbasis pada potensi alam setempat. Pendampingan yang diinginkan juga terkait pemasaran produk batiknya, adanya Museum Karst diharapkan akan menjadi ajang memasarkan produk batiknya.

Pengalaman Mitra 2 yang telah berhasil membentuk komunitas Kampoeng Batik Laweyan di Kota Surakarta akan ditransfer pada Program Kemitraan Masyarakat ini. Sementara itu permasalahan Mitra 2 saat ini pada input produk batik yang tidak bisa dibuat di Kampoeng Batik Laweyan sendiri, mereka harus bermitra dengan masyarakat lainnya. Mitra 2 bersemangat untuk mendampingi terbentuknya Desa Batik Karst Gunungsewu ini, diharapkan dengan bermitra dengan Mitra 1 ini pasokan batik yang dipasarkan di Kampoeng Laweyan akan terpenuhi, kebutuhan jangka panjang dalam usaha batik adalah kebutuhan pewarna alami yang banyak dipesan oleh konsumen yang peduli terhadap pelestarian lingkungan. Desa Ginggang ini layak dijadikan mitranya dalam pemenuhan kebutuhan batik dengan pewarna alaminya. Konon dari pengalaman pinisepuh, batik yang dicuci dari air di kawasan karst ini akan menghasilkan warna khas yang disukai konsumen batik luar negeri. Pola-pola batik yang akan dihasilkan dalam PKM ini menggambarkan fenomena kawasan karst dengan konsep eksokarst (fenomena luar) dan endokarst (fenomena dalam) dengan bentuk-bentuk kubah kapur dan gua-gua serta sungai bawah tanahnya sebagaimana pada Gambar 1 berikut.

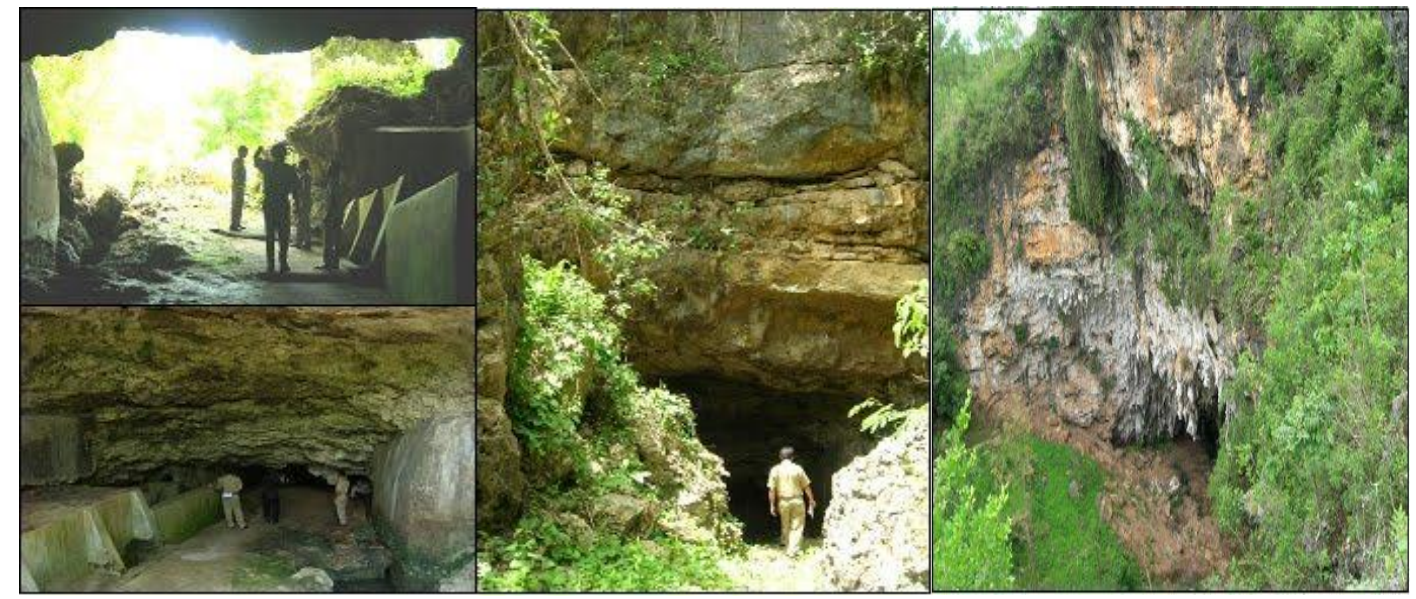

Gambar 1. Fenomena Eksokarst dan Endokarst Kawasan Karst Gunungsewu

Dari uraian analisis situasi tersebut dapat diketahui beberapa permasalahan kedua mitra dalam kaitannya upaya peningkatan sinergitas/integrasi keberadaan Museum Kasrt Gunungsewu sebagai World Heritage (Situs Warisan Dunia). Program kegiatan pengabdian pada masyarakat ini bertujuan menjadikan kawasan Desa Ginggang sebagai Desa Wisata yang berbasis pada potensi alam setempat. Permasalahan yang akan dicarikan solusi jawaban dalam kegiatan pengabdian ini sebagai berikut: (1) keterbatasan modal dan wawasan masyarakat Desa Ginggang dalam produk batik, (2) minimnya pengetahuan masyarakat tentang filosofi geomorfologi/bentangalam karst sebagai pola/motif batik yang menjadi keunikan dan mencerminkan karakter Desa Batik Kawasan Karst, (3) pentingnya penggunaan pewarna alami dalam produk batik yang dapat disediakan di Kawasan Karst ini sekaligus sebagai edukasi 
produk pewarna batik yang ramah lingkungan sebagai upaya pelestarian ekosistem karst, dan (4) pentingnya terbentuk sinergitas pemasaran Museum Karst Gunungsewu dengan usaha kegiatan pengabdian berbasis Desa Batik yang dibangun bersama dengan pelaku pasar Batik yang sudah maju/pengalaman.

\section{Metode}

Untuk menjawabpermasalahan-permasalahan yang dihadapi kedua Mitra, maka solusiyangditawarkanpada kegiatanpengabdian masyarakat ini meliputi: (1) bidangpenciptaan batik Karst Gunungsewu, solusi ini terkait dengan permasalahan penumbuhkan modal dan wawasan masyarakat Desa Ginggang terkait produk batik, luaran dari kegiatan ini berupa peningkatan tata nilai masyarakat dalam seni batik; (2) estetika batik Kawasan Karst Gunungsewu, solusi ini terkait dengan permasalahan fenomena bentangalam karst Gunungsewu serta gambaran endokarst dan eksokarst untuk gambaran pola/motif batik dengan pewarnaan alami yang menunjukkan kekhasan produk batik, luarannya berupa metode dan peningkatan kualitas produk; dan (3) pemasaran Produk Desa Batik Karst Gunungsewu, terkait solusi pemasaran produk dengan luaran inovasi dan merek dagang batiknya sekaligus promosi dan edukasi pelestarian ekosistem Kawasan Karst Gunungsewu sebagai Bentangalam Budaya milik Dunia (Word Heritage).

Metode pelaksanaan kegiatan meliputi tahapan atau langkah-langkah dalam melaksanakan solusi yang ditawarkan dalam Bidang Penciptaan Batik Karst Gunungsewu: (1)membuat pola dengan menggunakan dua cara yaitu pola langsung pada kain dan menggunakan pola dengan bantuan penggaris; (2) penglowongan, merupakan proses pemalaman atau pelekatan malam yang dilakukan ketika kain dalam keadaan belum diberi warna melalui teknik pencipratan dan teknik canthing/kuas; (3) pewarnaan pertama yang merupakan proses penciptaan batik dengan tujuan memberi warna pada kain dengan teknik esek dan teknik celup; (4) Njupiki atau mengambil merupakan proses pemalaman yang bertujuan menutupi atau menorehkan cairan malam padakain yangs udah diberi warna; (5) pewarnaan kedua, berfungsi untuk melebur dan meratakan hasil pewarnaan pertama dengan teknik celup; dan (6) pelorodan, merupakan perebusan yang dilakukan untuk melepaskan dan membersihkan malam yang melekat/menempel pada kain yang merupakan langkah terakhir dalam proses penciptaan batik.

Dalam kegiatan terkait Estetika Batik Kawasan Karst Gunungsewu, meliputi Langkahlangkah berikut: (1) pelatihan pemahaman filosofi geomorfologis terbentuknya bentang alam karst Gunungsewu dan filosofi pewarnaan menggunakan pewarna alami yang mencerminkan keunikan bentangalam karst pada motif batiknya; (2) melatih menerjemahkan gambaran morfologis karst didasarkan pada nilai estetis atau nilai murni,seperti penerapan gradasi warna, kontras value, tekstur kasar semu yang disebabkan oleh perbedaan raut dan persinggungan antar bentuk berupa titik, garis, dan bidang organik, serta memiliki arah, kedudukan, ukuran, dan gerak yang berbeda-beda sehingga memunculkan irama transisi, dominasi, kontras proporsi, dan kesatuan; ( 3 ) pelatihan nilai ekstra estetis atau nila itambahan yang terdapat pada motif yang diterapkan yang memiliki makna dari motif yang diterapkan, yaitu motif yang bermakna pelestarian bentang alam kawasan karst.

Selanjutnya dalam kegiatan Pemasaran Produk Desa Batik Karst Gunungsewu, dipahamkan bahwa sebagai warisan budaya Indonesia yang telah diakui dunia, batik Indonesia memiliki corak yang berbeda-beda di setiap daerahnya (Dewanti, Melati, \& Simbolon, 2013). Dengan semakin berkembangnya dunia digital saat ini, maka tidak mustahil jika batik produk Desa Batik Karst ini bisa semakin dikenal, melalui pelaksanaan pemasarannya menggunakan strategi marketing mix (bauran pemasaran) yaitu memperhatikan dan menjaga perpaduan antara produk, harga, promosi dan distribusi. Bersama Mitra 2 yang sudah berpengalaman memasarkan produk batik Kampoeng Batik Laweyan Solo, produk Desa Batik diharapkan akan mudah 
dipasarkan.Adapun gambaran pelaksanaan kegiatan pengabdian masyarakat ini ditunjukkan pada Gambar 2 dan 3 berikut.

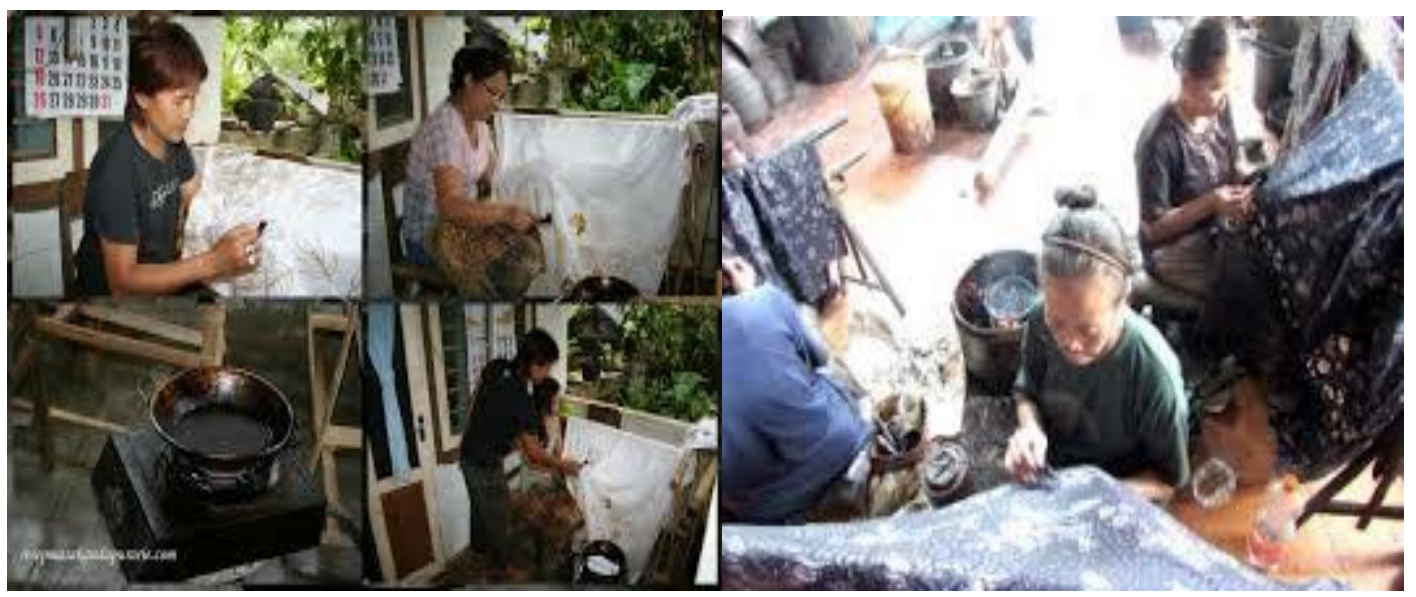

Gambar 2. Proses Penciptaan Batik Karst Gunungsewu

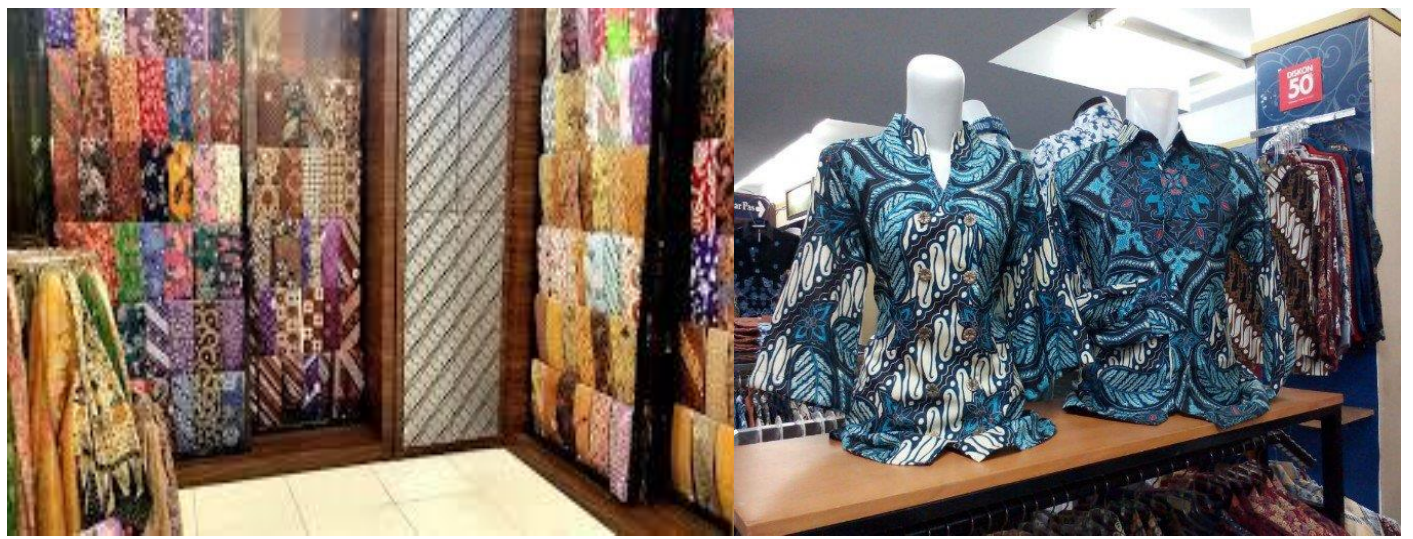

Gambar 3. Pemasaran Produk PKM (Widyaningrum, 2012).

\section{Hasil dan Pembahasan}

Pelaksanakan kegiatan yang telah dicapai yang berkaitan dengan hasil dari implementasipenyelesaian permasalahan Mitra 1 yang selama ini hanya sebagai penonton keberadaan Museum Karst Dunia yang berada di tengah desanya, mereka telah merasakan adanya kepemilikan akan desanya. Kegiatan pelatihan membatik telah membangkitkan kembali kenangan lama sebagai anak dan cucu pembatik, sehingga mereka semangat dalam mengikutipendampingan dalam pembuatan batik yang khas dan terintegrasi dengan pengenalan kawasan karst Gunungsewu. Pendampingan yang menyangkut potensi pewarna alami sebagai sumberdaya alam local berupa dedaunan yang selama ini dipahami sebagai semak-semak ternyata mempunyai nilai tinggi sebagai bahan pembuatan pewarna alami yang ramah lingkungan, sehingga untuk jangka panjang kebutuhan akan pewarna pada usaha batik itu akan terpenuhi dengan tidak menyebabkan kerusakan ekosistem karst Gunungsewu. Dengan kegiatan ini masyarakat merasakan akan keikutsertaannya dalam kegiatan pelestarian alam sebagaimana visi dan misi keberadaan Museum Karst Gunungsewu. Pola-pola motif batik yang menggambarkan informasi kekhasan bentangalam Karst Gunungsewu telah menjadikan masyarakat memahami proses kejadian bentangalam karst yang terbentuk jutaan tahun sebagai 
warisan dunia. Mitra 1 telah bersepakan menjadikan kawasan desanya sebagai Desa Wisata Batik yang berbasis pada potensi alam setempat. Pendampingan yang diinginkan juga terkait pemasaran produk batiknya, adanya Museum Karst diharapkan akan menjadi ajang memasarkan produk batiknya. Gambaran antusiasnya ibu-ibu PKK sebagai anggota Mitra 1 tersebut dapat dilihat pada Gambar 4 berikut.

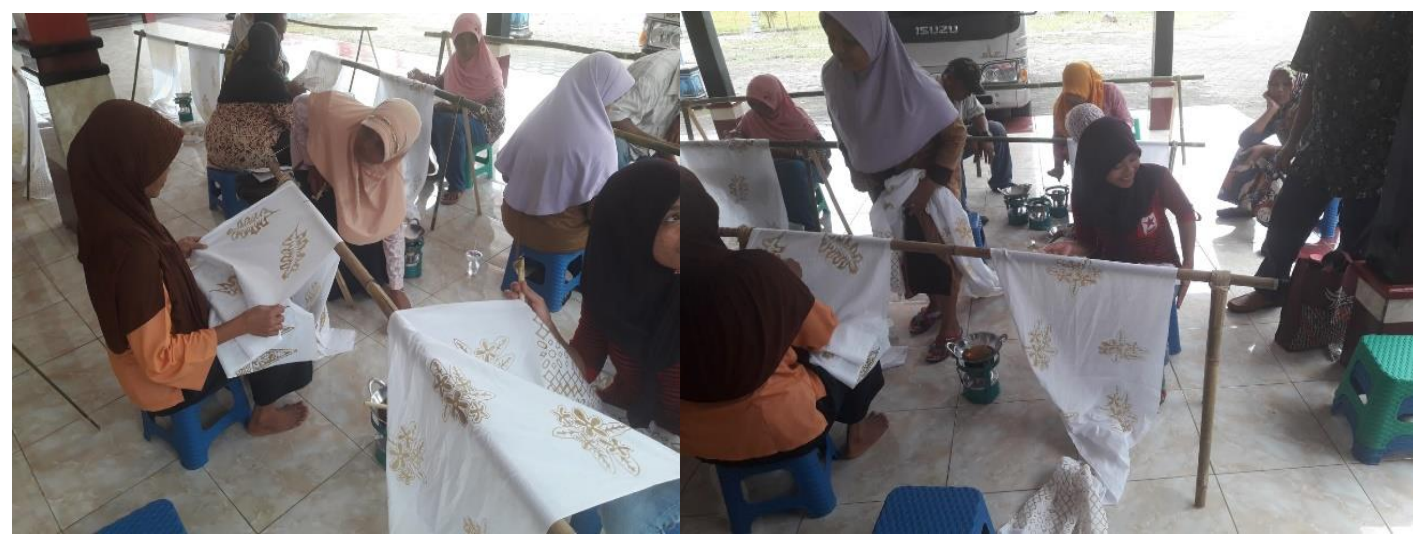

Gambar 4. Peserta Pelatihan (Mitra 1) Antusias dalam Pelatihan Pembuatan Pola Batik

Mitra 2 yang mempunyai pengalaman panjang dalam usaha batik yang telah berhasil membentuk komunitas Kampoeng Batik Laweyan di Kota Surakarta berhasilmentransfer pada masyarakat anggota Mitra 1 ini. Permasalahan Mitra 2 saat ini pada input produk batik yang tidak bisa dibuat di Kampoeng Batik Laweyan sendiri, dengan kegiatan ini mereka telah memperoleh mitra dengan masyarakat di Desa Ginggang. Mitra 2 telah bersemangat dalam mendampingi terbentuknya Desa Batik Karst Gunungsewu ini, bahkan segenap perangkat Desa ikut dalam proses pelatihan ini. Diharapkan dengan bermitra dengan Mitra 1 ini pasokan batik yang dipasarkan di Kampoeng Laweyan akan terpenuhi, kebutuhan jangka panjang dalam usaha batik adalah kebutuhan akan pewarna alami yang banyak dipesan oleh konsumen yang peduli terhadap pelestarian lingkungan. Desa Ginggang ini layak dijadikan mitranya dalam pemenuhan kebutuhan batik dengan pewarna alaminya. Konon dari pengalaman pinisepuh, batik yang dicuci dari air di kawasan karst ini akan menghasilkan warna khas yang disukai konsumen batik luar negeri. Pola-pola batik yang akan dihasilkan dalam pengabdian kepada masyarakat inimenggambarkan fenomena kawasan karst dengan konsep eksokarst (fenomena luar) dan endokarst (fenomena dalam) dengan bentuk-bentuk kubah kapur dan gua-gua serta sungai bawah tanahnya hasil pengabdian telah dilakukan dalam kaitannya dengan penyelesaian permasalahan yang dihadapi mitra. Gambaran semangat Kelompok ibu-ibu PKK beserta segenap perangkat Desa Ginggang dapat dilihat pada Gambar 5 berikut. 


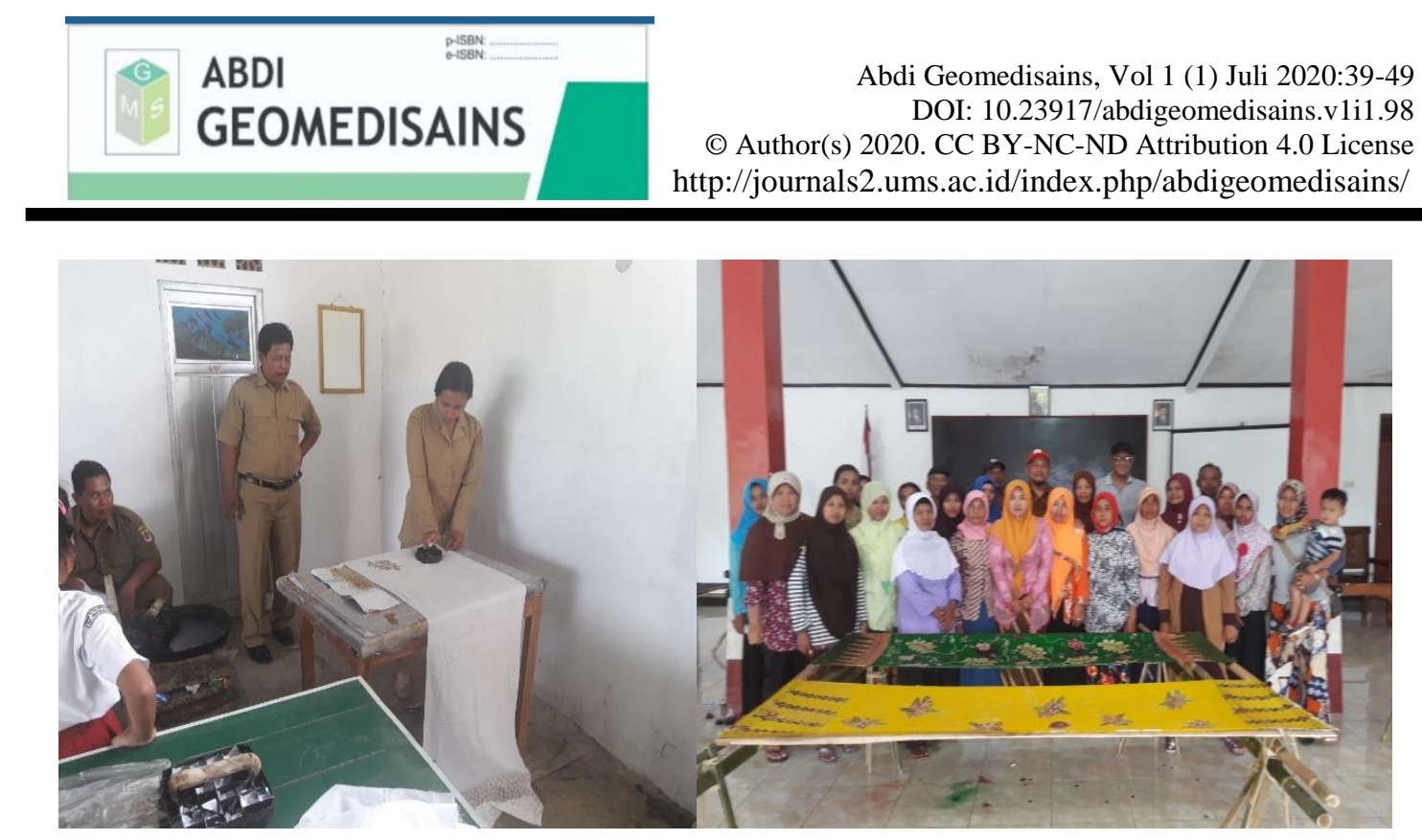

Gambar 5. Kelompok Ibu-ibu PKK didampingi Perangkat Desa dalam Pelatihan

Pemahaman terkait dengan pelestarian Ekosistem Karst oleh ibu-ibu PKK beserta perangkat Desa Ginggan, setelah pelaksanaan pelatihan oleh Tim Pengabdian Masyarakat UMS ini semakin meningkat. Masyarakat telah memahami bahwa ciri utama kawasan karst adalah terdapatnya cekungan-cekungan tertutup yang disebut sebagai dolin, apabila dolin saling menyatu membentuk uvala. Di beberapa tempat, dolin dapat terisi air membentuk danau dolin, dikenal di Desa Ginggang dengan istilah "telogo". Kenampakan permukaan daerah karst selain doline dan uvala adalah polje, ponor, pinacle, menara karst, atau kubah karst. Kombinasi dolin dan kubah menyebabkan panorama karst menjadi unik dengan bukit-bukit yang terhampar luas.Keunikan lain dari kawasan karst adalah keberadaan goa dan sungai bawah tanah. Goa-goa tersebut pada umumnya bertingkat dengan ukuran kurang dari satu meter hingga ratusan meter persegi dengan bentuk vertikal miring maupun horisontal. Goa-goa karst hampir semuanya dihiasi dengan ornamen (speleothem) yang sangat beragam dari mulai yang sangat kecil (helectite) hingga yang sangat besar (column) dengan bentuk dan warna yang bervariasi (Adji dan Haryono, 2017). Karst Gunung Sewu dicirikan dengan berkembangnya kubah karst (Kegle Karst), yaitu bentukan positif yang tumpul, tidak terjal atau sering diistilahkan kubah sinusoidal (Lehman, 1936 dalam Adji dan Haryono, 2017). Ketinggian tempat berkisar antara $300-500 \mathrm{~m}$ dpal dan relief bervariasi antara $50-150 \mathrm{~m}$ dpal. Batuan gamping di Karst Gunung Sewu berumur Miosen dan mengalami karstifikasi mulai akhir pliosen hingga awal pleistosen. Karst gunung sewu juga dicirikan dengan bentukan doline yang setiap musim penghujan selalu terisi air yang kemudian disebut telaga, yang jumlahnya ratusan. Luas karst Gunung Sewu mencapai $3300 \mathrm{~km}^{2}$ yang meliputi Propinsi DIY, Jawa Tengah, dan Propinsi Jawa Timur.

Masyarakat yang belum mengerti mengenai kawasan tersebut sebagian masih berpandangan bahwa karst merupakan kawasan gersang, tandus, sulit air dan prasarana kurang memadai serta tidak menarik. Bagian masyarakat yang berpandangan tersebut didominasi kaum mudanya, sehingga mereka memilih mencari kerja di kota-kota besar (Jakarta, Surabaya, Semarang, dan Surakarta). Kalangan masyarakat yang lainnya pada kenyataannya memahami bahwa kawasan karst menyimpan banyak sekali potensi yang dapat dimanfaatkan untuk kesejahteraan masyarakat.Pada dasarnya, karst bukan kawasan pertambangan karena merupakan daerah penyangga ketersediaan airnamun juga menjadi kawasan wisata budaya yang menarik (Tyas, Vitdiawati, \& Nusantari, 2016). Kawasan Perbukitan Karst Gunung Sewu merupakan geopark di Kabupaten Gunungkidul yang telah ditetapkan menjadi menjadi salah satu GGN (Global Geopark Network). Mengingat pentingnya ekosistem karst dan batuan kapur merupakan SDA non-renewable, maka perlu dilakukan konservasi untuk mempertahankan fungsi ekologi. 
Kondisi kawasan geopark Gunungsewu saat ini telah dipahami sebagai kawasan geografis dimana situs-situs warisan geologis menjadi bagian dari konsep perlindungan, pendidikan dan pembangunan berkelanjutan, dengan konsep manajemen pembangunan kawasan secara berkelanjutan yang memadu-serasikan 3 keragaman alam yaitu geodiversity, biodiversity, dan cultural diversity. Pendampingan kepada masyarakat melalui program pengabdian masyarakat ini dalam rangka pembelajaran kepada masyarakat akan pentingnya pelestarian ekosistem karst, sekaligus peran masyarakat dalam upaya pelestarian ekosistem karst dengan membatik bernuansa karst.

Sementara dalam proses pendampingan membatik ini, juga ada penjelasan terkait sejarah pembatikan di Indonesia bahwa membatik berkait erat dengan perkembangan kerajaan Majapahit dan penyebaran ajaran Islam di Tanah Jawa. Pengembangan batik banyak dilakukan pada masa-masa kerajaan Mataram, kemudian pada masa kerajaan Solo dan Yogyakarta(Ulum, 2016).Kesenian batik ini di Indonesia telah dikenal sejak zaman kerajaan Majapahit dan terus berkembang kepada kerajaan dan raja-raja berikutnya. Meluasnya kesenian batik ini menjadi milik rakyat Indonesia (khususnya suku Jawa) mulai akhir abad ke-18 atau awal abad ke-19, merupakan kesenian gambar di atas kain untuk pakaian yang menjadi salah satu kebudayaan keluarga raja-raja Indonesia zaman dulu. Awalnya batik dikerjakan hanya terbatas dalam keraton saja dan hasilnya untuk pakaian raja dan keluarga serta para pengikutnya, karena banyak dari pengikut raja yang tinggal di luar keraton, maka kesenian batik ini dibawa oleh mereka keluar keraton dan dikerjakan di tempatnya masing-masing.Menilik dari sejarahnya, batik telah mengakar dalam sejarah bangsa Indonesia. Batik tidak hanya tumbuh dan berkembang di pulai Jawa, tetapi juga di luar pulau Jawa dengan keragaman corak dan motif batik yang menunjukkan kekhasan masing-masing daerah. Motif-motif tersebut tidak hanya menjadi ciri khas daerah, tetapi juga menjadi simbol budaya daerah tersebut. Motif batik Ekosistem Karst Gunungsewu ini diharapkan menjadi kekhasan batik di Desa Ginggang, Kecamatan Pracimantoro, Kabupaten Wonogiri, Jawa Tengah sekaligus menjadi sinergitas upaya pelestarian ekosistem karst sendiri.

Indonesia adalah negara yang terdiri dari berbagai macam budaya (multikutur) yang juga memiliki suku yang beragam (multietnik). Hal itu dapat kita telusuri di berbagai daerah, dari Sabang sampai Merauke, berdasarkan keanekaragaman tersebut dalam pergaulan Internasional Indonesia dikenal sebagai negara yang multikultur dan multietnik (Adi, 2011).Keanekaragaman budaya yang dimiliki oleh negara ini tentunya mempunyai banyak sisi positif, salah satunya adalah Indonesia bisa dikenal di dunia internasional melalui budayanya yang sangat kaya dan beragam, disamping itu pula budaya ini bisa digunakan sebagai daya tarik atau pemikat untuk mendatangkan wisatawan asing. Namun kurangnya perhatian terhadap pelestarian budaya daerah, baik dari pemerintah maupun masyarakat mengakibatkan budaya-budaya tersebut terancam hilang dari kedaulatan Indonesia ditengah arus globalisasi.Globalisasi dan westernisasi yang melanda kawasan Asia Tenggara khususnya Indonesia, menjadikan masyarakatnya tidak peduli dan kurang melestarikan budayanya sehingga budaya tersebut menjadi terabaikan. Berdasarkan permasalahan tersebut, maka kegiatan pengabdian masyarakat di Desa Ginggang ini diharapkan akan mempromosikan sinergitas kegiatan pariwisata alam dengan pemberdayaan masyarakat dalam pelestarian ekosistem karst dan membatik. Selanjutnya konsep akhir dari kegiatan pengabdian masyarakat ini dapat dilihat melalui gambaran spasial berikut (lihat Gambar 6 berikut). 

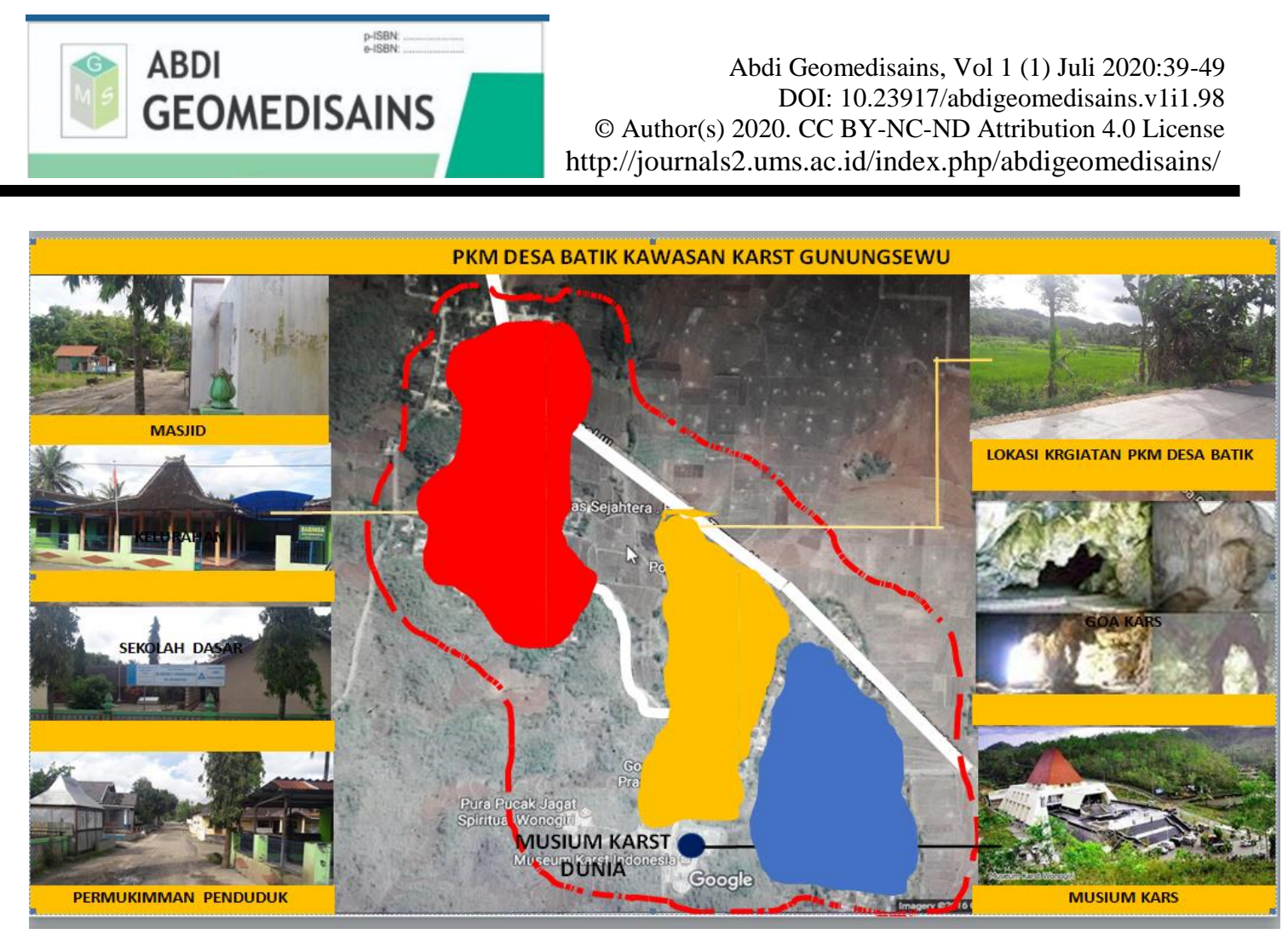

Gambar 6. Konsep pengembangan Desa Batik Kawasan Karst Gunungsewu

Masyarakat Desa Ginggang telah memahami juga bahwa semenjak diakuinya batik sebagai warisan asli budaya nasional Indonesia, penggunaannya diapresiasi oleh bangsa Indonesia secara luas. Produk batik tidak hanya digunakan pada waktu acara resmi seperti pernikahan atau event tertentu tapi juga ada himbauan pemerintah, misal sekali dalam seminggu yaitu hari Jumat mengenakan batik menjadi trend fashion(Tiningrum, 2014). Masyarakat Desa ginggang menyambut secara antusias, nantinya batik dengan motif Pelestarian Ekosistem Karst menjelma menjadi gerakan batik nasional. Kondisi ini cukup kondusif bagi perkembangan batik di Indonesia pada umumnya dan Surakarta pada khususnya yang menjadikan bisnis batik ini menjadi semakin menjanjikan (Yuliati, 2010). Melihat kenyataan ini membawa konsekuensi semakin ketatnya persaingan dibidang bisnis batik dan bahan sandang. Komunitas pembatik Desa Ginggang perlu dinaungi dalam kelompok pengusaha kecil (industri rumah tangga) dalam suatu Usaha Kecil Menengah (UKM) Batik Karst di Surakarta, untuk tetap bisa bertahan dalam persaingan yang cukup ketat maka kepuasan pelanggan menjadi suatu hal yang harus diperjuangkan. Dengan demikian setiap Usaha Kecil Menengah (UKM) dituntut menggunakanstrategi pemasaran yang tepat. Variabel promotion mempunyai pengaruh positif signifikan terhadap keputusan pembelian, sehingga variabel ini memberikan pengaruh terbesar terhadap keputusan pembelian secara signifikan. Oleh karenanya Usaha Kecil Menengah Batik Desa Ginggang telah disiapkan terintegrasi dengan promosi Museum Karst Dunia dengan memberikan perhatian serius terhadap space kegiatan promosi yang dilakukan baik dari sisi kualitas maupun kuantitasnya bersamaan promosi museum karst tersebut. Mitra-1 memahami bahwa sebelum mencapai pada tahap keputusan membeli atau tidak, seorang pembeli melewati tahap pengenalan masalah, pencarian informasi dan penilaian alternatif. Melalui kegiatan promosi inilah pemasar membawa konsumen menyadari akan kebutuhan yang harus dipenuhi, manfaat produk berbeda-bedadan produk yang ditawarkan lebih banyak manfaatnya dan dimana memperolehnya.

\section{Simpulan}

Pelaksanaan kegiatan pengabdian kepada masyarakat ini telah memberi solusip ada Mitra-1 dalam Bidang Penciptaan Batik Karst Gunungsewu yang meliputi : (1) membuat pola dengan menggunakan dua cara yaitu pola langsung pada kain dan menggunakan pola 
dengan bantuan penggaris; (2) penglowongan, merupakan proses pemalaman atau pelekatan malam yang dilakukan ketika kain dalam keadaan belum diberi warna melalui teknik pencipratan dan teknik canthing/kuas; (3) pewarnaan pertama yang merupakan proses penciptaan batik dengan tujuan memberi warna pada kain dengan teknik esek dan teknik celup; (4) Njupiki atau mengambil merupakan proses pemalaman yang bertujuan menutupi atau menorehkan cairanmalampadakainyangsudah diberiwarna; (5) pewarnaan kedua, berfungsi untuk melebur dan meratakan hasil pewarnaan pertama dengan teknik celup; dan (6) peloro dan, merupakan perebusan yang dilakukan untuk melepaskan dan membersihkan malam yang melekat/menempel pada kain yang merupakan langkah terakhir dalam proses penciptaan batik.

Dalam kegiatan terkait Estetika Batik Kawasan Karst Gunungsewu, kegiatannya telah memahamkan Mitra-1 maupun Mitra-2 akan pentingnya: (1) pemahaman filosofi geomorfologis terbentuknya bentang alam karst Gunung sewu dan filosofi pewarnaan menggunakan pewarna alami yang mencerminkan keunikan bentangalam karst pada motif batiknya; (2) menerjemahkan gambaran morfologis karst daidasarkan pada nilai estetis atau nilai murni,seperti penerapan gradasi warna, kontras value, tekstur kasar semu yang disebabkan oleh perbedaan raut dan persinggungan antar bentuk berupa titik, garis, dan bidang organik, serta memiliki arah,kedudukan, ukuran,dan gerak yang berbeda-beda sehingga memunculkan irama transisi,dominasi,kontras proporsi,dan kesatuan; d a n (3) nilai ekstra estetis atau nilai tambahan yang terdapat pada motif yang diterapkan yang memiliki makna dari motif yang diterapkan,yaitu motif yang bermakna pelestarian bentang alam kawasan karst.

\section{Persantunan}

Ucapan terima kasih dan apresiasi diberikan kepada Rektor Universitas Muhammadiyah Surakarta cq. Ketua Lembaga Penelitian dan Pengabdian kepada Masyarakat UMS yang telah membiayai dan mendampingi dalam pelaksanaan pengabdian kepada masyarakat di Desa Ginggang, Kecamatan Pracimantoro, Kabupaten wonogiri ini. Apresiasi yang dalam kepada Kepala Desa Ginggang dan Kelompok Ibu-ibu PKK Desa Ginggang yang dengan antusias dalam kegiatan pendampingan membatik dan sosialisasi pentingnya pelestarian ekosistem karst sebagai warisan dunia. Apresiasi juga kami sampaikan kepada segenap tim Mitra-2 dari komunitas Batil Kampung Laweyan Kota Solo yang telah meluangkan waktunya dalam mendampingi ibu-ibu PKK dalam proses membatiknya. Semoga kegiatan ini dapat berlanjut dalam rangkaian pendampingan dan pemberdayaan program penguatan pembangunan desa yang lainnya.

\section{Referensi}

Adi, P. R. (2011). Diplomasi Pemerintah Indonesia dalam memperoleh pengakuan Batik dari Unesco (Doctoral Dissertation, University of Muhammadiyah Malang).

Adji, T. N., \& Haryono, E. (2017). Kawasan Karst dan Prospek Pengembangannya di Indonesia. Seminar PIT IGI di Universitas Indonesia, 26-27 Oktober 1999.

Dewanti, R., Melati, I., \& Simbolon, F. (2013). Pengembangan Model Daya Saing UMKM Batik Melalui ECS. Binus Business Review, 4(1), 41-57

Lusianti, L. P., \& Rani, F. (2012). Model Diplomasi Indonesia Terhadap UNESCO Dalam Mematenkan Batik Sebagai Warisan Budaya Indonesia Tahun 2009. Jurnal Transnasional, 3(02), 1-19

Moersid, A. F. (2013). Re-invensi batik dan identitas indonesia dalam arena pasar global. Jurnal Ilmiah WIDYA, l(1), 121-128.

Nuraini, F., \& Pramono, H. (2013). Kajian Karakteristik Dan Potensi Kawasan Karst Untuk Pengembangan Ekowisata Di Kecamatan Ponjong Kabupaten Gunungkidul. Geomedia: Majalah Ilmiah dan Informasi Kegeografian, 11(1), 109-127. 
Tiningrum, E. (2014). Pengaruh Bauran Pemasaran Terhadap Keputusan Pembelian Batik di Uasaha Kecil Menengah Batik Surakarta. ADVANCE, 1(2). Edisi Pebruari 2014,1(2).

Tyas, D. N., Vitdiawati, R., \& Nusantari, R. (2016). Konservasi dan Pemanfaatan Berkelanjutan Kawasan Karst Gunung Sewu Sebagai Bagian Geopark Untuk Mempertahankan Fungsi Ekologi. In Symbion (Symposium on Biology Education): Proceeding, Departement of Biology Universitas Ahmad Dahlan, 311-324.

Ulum, I. (2016). Batik dan Kontribusinya Terhadap Perekonomian Nasional. Jurnal Bestari, (42), 21-32.

Widawati, H., Rindarjono, M., \& Soegiyanto, H. (2017). Persepsi Masyarakat dalam Upaya Konservasi pada Geopark Gunung Sewu Sebagai Aset Geowisata di Kabupaten Pacitan. Prosiding Seminar Nasional Geografi UMS 2017, PENGELOLAAN SUMBERDAYA WILAYAH BERKELANJUTAN, ISBN:978-602-361-072-3.

Widyaningrum, D. E. (2012). Strategi Pemasaran Kampung Batik Laweyan Solo. Jurnal Manajemen Pemasaran Universitas Indonesia.

Yuliati, D. (2010). Mengungkap sejarah dan motif batik Semarangan. Paramita: Historical Studies Journal, 20(1), 11-20.

Attribution (CC-BY-NC-ND) license (http://creativecommons.org/licenses/by/4.0/). 